\title{
Comparison of Performance Measurements of Photovoltaic Modules during Winter Months in Taxila, Pakistan
}

\author{
Muhammad Anser Bashir, ${ }^{1}$ Hafiz Muhammad Ali, ${ }^{1}$ Shahid Khalil, ${ }^{1}$ \\ Muzaffar Ali, ${ }^{1}$ and Aysha Maryam Siddiqui ${ }^{2}$ \\ ${ }^{1}$ Department of Mechanical Engineering, University of Engineering and Technology, Taxila 47050, Pakistan \\ ${ }^{2}$ Department of Electrical Engineering, COMSATS Institute of Information Technology, Wah 47040, Pakistan \\ Correspondence should be addressed to Hafiz Muhammad Ali; h.m.ali@uettaxila.edu.pk
}

Received 12 November 2013; Revised 13 January 2014; Accepted 14 January 2014; Published 26 February 2014

Academic Editor: Niyaz Mohammad Mahmoodi

Copyright (C) 2014 Muhammad Anser Bashir et al. This is an open access article distributed under the Creative Commons Attribution License, which permits unrestricted use, distribution, and reproduction in any medium, provided the original work is properly cited.

\begin{abstract}
This paper presents the comparative performance evaluation of three commercially available photovoltaic modules (monocrystalline, polycrystalline, and single junction amorphous silicon) in Taxila, Pakistan. The experimentation was carried out at outdoor conditions for winter months. Power output, module efficiency, and performance ratio were calculated for each module and the effect of module temperature and solar irradiance on these parameters was investigated. Module parameters showed strong dependence on the solar irradiance and module temperature. Monocrystalline and polycrystalline modules showed better performance in high irradiance condition whereas it decreased suddenly with decrease in irradiance. Amorphous solar module also showed good performance in low irradiance due to its better light absorbing characteristics and thus showed higher average performance ratio. Monocrystalline photovoltaic module showed higher monthly average module efficiency and was found to be more efficient at this site. Module efficiency and performance ratio showed a decreasing trend with increase of irradiance and photovoltaic module back surface temperature.
\end{abstract}

\section{Introduction}

The performance testing of PV modules at outdoor conditions is required to have an accurate estimation of output of PV modules under specific climate. The rated values of PV modules provided by the manufacturer are based on the standard test conditions (i.e., irradiance $1000 \mathrm{~W} / \mathrm{m}^{2}$, module temperature $25^{\circ} \mathrm{C}$, and $\mathrm{AM} 1.5$ ) which do not meet operating outdoor conditions due to the varying outdoor parameters [1].

Different researches and scientists have worked on the performance evaluation of photovoltaic system under different climates. Amin et al. [2] conducted an experimental study to evaluate the performance of four PV modules (monocrystalline, polycrystalline, amorphous silicon, and copper indium diselenide (CIS)) in Malaysia for three consecutive days. The results showed that CIS module has higher performance ratio while c-Si module has high module efficiency among all the modules tested. Carr and Pryor [3] evaluated and compared the performance of five different PV modules using an outdoor facility in the climate of Perth for one year. They found that amorphous silicon module has highest performance ratio with maximum energy produced at that site. Akhmad et al. [4] investigated the outdoor performance of polycrystalline and amorphous silicon module and found that amorphous silicon module has better efficiency and output power in summer. A similar study was conducted at the site of Norway [5] to investigate the performance of three PV modules (monocrystalline, polycrystalline, and triple junction amorphous silicon). They concluded that monocrystalline module was better in terms of module efficiency and overall power production. According to the installation environment, PV power generating systems can be divided into independent PV systems and grid-connected PV systems. Grid-connected solar PV system is the fastest growing power generating technology [6]. 
Module temperature affects the output of PV modules. The temperature effect of the module output has been reported by different researchers [7-10]. Sanusi et al. [11] investigated the effect of ambient temperature on PV modules for three years and found a linear behaviour between output power and ambient temperature. One important factor associated with the amorphous silicon module is the effect of photodegradation. The a-Si modules undergo some degradation resulting in a decrease in module performance [12-14]. The solar irradiance effect on the output of PV modules was also investigated by the different researchers $[15,16]$. Some unavoidable environmental factors including wind speed and direction, dust accumulation, humidity, and ambient temperature also effect the performance of PV modules $[17,18]$. Catelani et al. [19] investigated the effect of dust and pollution on PV module performance using statistical approach. From the statistical hypothesis test, the maximum power showed decrement with the dust accumulation on panel surface. A theoretical model was proposed by Cristaldi et al. [20] to predict the impact of dust from economical point of view. The mathematical model takes into account both the cost due to reduction of the energy production and the maintenance operation cost. This model allows defining the suitable maintenance and monitoring policy for a specific plan. An investigation of dust effect on the performance of PV modules was performed by the Catelani et al. [21] by using method of a Failure Modes, Effects, and Criticality Analysis (FMECA). Mekhilef et al. [22] investigated the effect of dust, humidity, and air velocity simultaneously. They concluded that effect of each parameter should not be studied separately during estimating the cell efficiency by ignoring the other factors.

A handful number of research reports of solar energy potential in Pakistan have been reported in open literature. The average daily sunshine hours in most areas of country are 7-8 [23]. The annual sunshine hours are about 30003300 [24]. The daily average global solar irradiance is 19$20 \mathrm{MJ} / \mathrm{m}^{2} / \mathrm{d}$ and mean annual solar irradiance is $15-21 \mathrm{MJ} / \mathrm{m}^{2}$ in Pakistan [25]. Bashir et al. [26] reported experimental data for different PV modules for January and found monocrystalline module more efficient (this data will be used in the analysis of present investigation for the sake of completeness of data).

The aim of present study is to evaluate the performance of commercially available PV modules over the winter months and to analyze the effect of temperature and solar irradiance on their output parameters.

\section{Experimental Setup and Methodology}

Three commercially available PV modules (monocrystalline, polycrystalline, and single junction amorphous silicon modules) used in this study were placed on a south facing structure at a fixed tilt angle of $48^{\circ} \mathrm{C}$ with horizontal plane (Figure 1). Table 1 shows the technical specifications and physical dimensions of PV modules used in this study. Each of the PV modules was connected with the temperature sensors and digital multimeters.
The global solar radiation (GSR) in plane with the PV modules was measured using a pyranometer TBQ-2 (sensitivity $11.346 \mu \mathrm{V} / \mathrm{Wm}^{-2}$, spectral range $280 \sim 3000 \mathrm{~nm}$ ) along with a solar radiation monitoring system (range 0$2000 \mathrm{~W} / \mathrm{m}^{2}$, accuracy error $<2 \%$, resolution $1 \mathrm{~W} / \mathrm{m}^{2}$ ) which records data and transfers it into PC. The K-type thermocouples were used for module temperature measurement connected with digital multimeters and attached at the middle of each module with the help of heat conducting paste. A schematic of experimental setup is shown in Figure 2. Digital multimeters (Agilent $34401 \mathrm{~A}$ ) were used to measure the current and voltage of PV modules. An electronic load was connected to PV modules to vary the output of the PV modules from zero to maximum. The module parameters $\left(P_{\max }, I_{\max }, V_{\max }, I_{\mathrm{sc}}\right.$, and $\left.V_{\mathrm{oc}}\right)$ were obtained from $I-V$ curve drawn through measured current and voltage data.

The experiments were performed in Taxila, Pakistan (Latitude 33.7 N, longitude 72.8 E). Measurements were taken for alternative days on hourly basis from 8 am to $5 \mathrm{pm}$. The performance related parameters of PV modules were calculated using following equations.

Maximum power:

$$
P_{m}=V_{m} \times I_{m}
$$

Fill factor:

$$
\mathrm{FF}=\frac{\left(V_{m} \times I_{m}\right)}{\left(V_{\mathrm{oc}} \times I_{\mathrm{sc}}\right)}
$$

Normalized power output efficiency:

$$
\eta_{p}=\left(\frac{P_{\mathrm{mea}}}{P_{m(\mathrm{STC})}}\right) \times 100 .
$$

Module efficiency:

$$
\eta_{\text {mod }}=\left(\frac{P_{\text {mea }}}{\left(E \times A_{a}\right)}\right) \times 100 .
$$

Performance ratio:

$$
\mathrm{PR}=\frac{\left(P_{\mathrm{mea}} / P_{m(\mathrm{STC})}\right)}{(E / 1000)} .
$$

Direct solar irradiance:

$$
E_{H}=E_{D} \times \cos \delta
$$

The output power of PV modules used in this study was not the same so for comparison purpose we have normalized the output power of PV modules with their output power at STC.

The module efficiency depends upon the active area of the modules. Active area is the actual area of the module in which photovoltaic process takes place. The PR is the performance of modules at actual operating conditions compared to their performance at STC. 


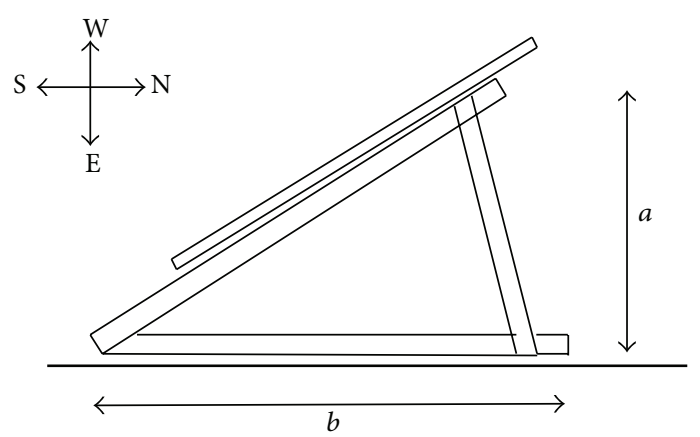

FIgURE 1: Positioning of photovoltaic modules showing direction towards sun and tilt angle.

TABLE 1: Physical dimensions, rated technical specifications, and measured values of photovoltaic modules.

\begin{tabular}{|c|c|c|c|}
\hline & c-Si & $\mathrm{p}-\mathrm{Si}$ & $\mathrm{a}-\mathrm{Si}$ \\
\hline \multicolumn{4}{|c|}{ Dimensions } \\
\hline Module dimension $(\mathrm{mm} \times \mathrm{mm})$ & $690 \times 540$ & $690 \times 455$ & $1250 \times 640$ \\
\hline Cell dimensions $(\mathrm{mm} \times \mathrm{mm})$ & $156 \times 52$ & $156 \times 45$ & $1220 \times 610$ \\
\hline No. of cells (in series) & $4 \times 9$ & $4 \times 9$ & 1 \\
\hline Total cells area $\left(\mathrm{m}^{2}\right)$ & 0.292 & 0.2527 & 0.7442 \\
\hline \multicolumn{4}{|c|}{ Rated values } \\
\hline Maximum power, $P_{\max }(\mathrm{W})$ & 45 & 40 & 40 \\
\hline Maximum current, $I_{\max }(\mathrm{A})$ & 2.2 & 2.3 & 0.47 \\
\hline Maximum voltage, $V_{\max }(\mathrm{V})$ & 18.2 & 17.4 & 30.4 \\
\hline Short circuit current, $I_{\mathrm{sc}}(\mathrm{A})$ & 2.7 & 2.66 & 0.65 \\
\hline Open circuit voltage, $V_{\mathrm{oc}}(\mathrm{V})$ & 21.6 & 21.6 & 54.8 \\
\hline Temp. coefficient of $I_{\mathrm{SC}}\left(\% /{ }^{\circ} \mathrm{C}\right)$ & +0.05 & +0.06 & +0.09 \\
\hline Temp. coefficient of $V_{\mathrm{OC}}\left(\% /{ }^{\circ} \mathrm{C}\right)$ & -0.35 & -0.36 & -0.29 \\
\hline Temp. coefficient of $P_{M}\left(\% /{ }^{\circ} \mathrm{C}\right)$ & -0.45 & -0.5 & -0.20 \\
\hline \multicolumn{4}{|c|}{ Measured values } \\
\hline Avg. global solar irrad. $\left(\mathrm{W} / \mathrm{m}^{2}\right)$ & 625.7 & 625.7 & 625.7 \\
\hline Avg. ambient temp. $\left({ }^{\circ} \mathrm{C}\right)$ & 18.1 & 18.1 & 18.1 \\
\hline Avg. module temp. $\left({ }^{\circ} \mathrm{C}\right)$ & 28.5 & 28.1 & 27.2 \\
\hline Avg. module current (A) & 1.4 & 1.2 & 0.5 \\
\hline Avg. module voltage (V) & 21.1 & 20.8 & 57.1 \\
\hline Avg. module power (W) & 23.4 & 19.7 & 22.2 \\
\hline Avg. power output Eff. (\%) & 52 & 49.2 & 55.5 \\
\hline Avg. module efficiency (\%) & 13.1 & 12.5 & 5.5 \\
\hline Avg. performance ratio & 0.85 & 0.8 & 1.03 \\
\hline
\end{tabular}

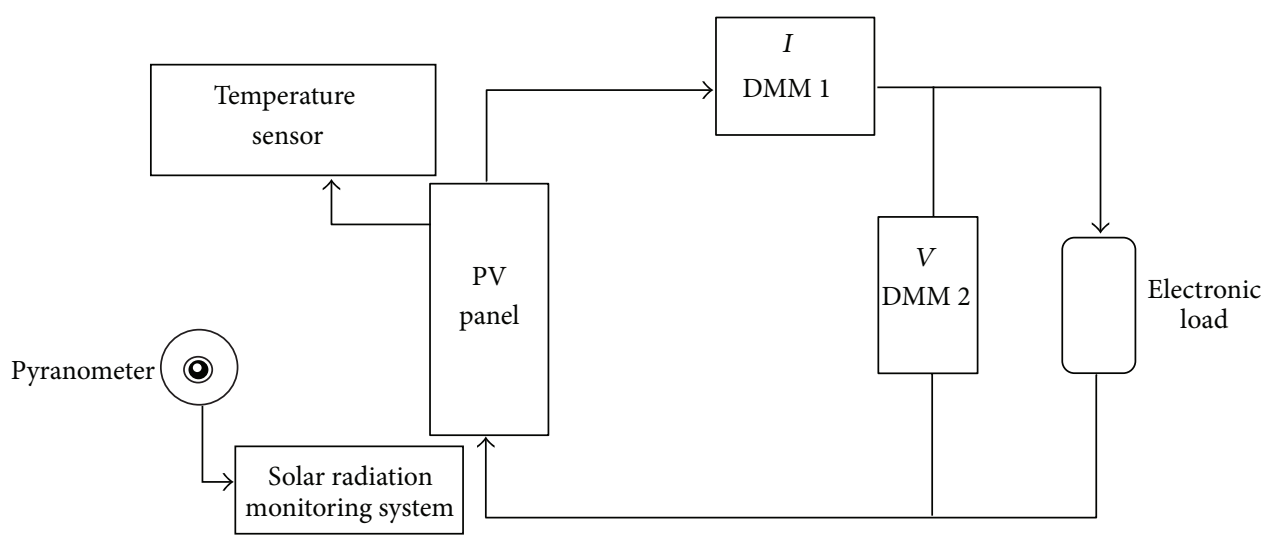

FIGURE 2: Schematic diagram of experimental setup. 


\section{Results and Discussion}

The data of alternative days of winter months was recorded and comparison was made. During the study, the month of February was cloudier as compared to other months. The data of two days in February could not be taken due to heavy rain.

Figure 3 shows the hourly average global solar radiation during the study. The monthly average global solar radiation was 569,591 , and $713 \mathrm{~W} / \mathrm{m}^{2}$ for January [26], February, and March, respectively. The hourly average output power of PV modules for winter months is shown in Figure 4. The output power has shown a linear behavior with solar irradiance and maximum output power was found to be at $12 \mathrm{pm}$ corresponding to maximum solar irradiance.

The variation of daily average output power is shown in Figure 5. At higher solar irradiance (above $400 \mathrm{~W} / \mathrm{m}^{2}$ ), c-Si module has shown higher daily average output power but aSi module has better output power at low solar irradiance (below $400 \mathrm{~W} / \mathrm{m}^{2}$ ) due to its better light absorbing characteristic, also found by Munoz-Garc1 et al. [27]. This is also clear from Figure 6, where a-Si shows better normalized output power efficiency at low solar irradiance which becomes less than crystalline silicon modules at high solar irradiance.

Table 2 shows a good comparison of average horizontal GSR of clear sky days measured in this study and already published data [28] of Islamabad for the months of January, February, and March.

3.1. Temperature Analysis. Module temperature depends upon solar irradiance as well as ambient temperature. The variation of hourly average ambient and modules temperature is shown in Figure 7. The modules temperature stays above to the ambient temperature for all three months. This is because of heat production during photovoltaic process. The a-Si module has shown lowest average module temperature. This is due to its large surface area which causes more heat convection between the module surface and surrounding air resulting in the cooling of module. The module temperature showed an increasing trend with solar irradiance. After $4 \mathrm{pm}$, the module temperature becomes lower than the ambient temperature due to sudden decrease of solar irradiance which slows down the photovoltaic process and module temperature decreases. The average module temperature is higher in March due to high average solar irradiance.

The output power of PV modules increased with module temperature but has shown a decrement from linear trend at high module temperature as shown in Figure 8. This effect is due to decrease of modules open circuit voltage $V_{\text {oc }}$ at high module temperatures as reported by Sze [29]. The output power of a-Si module was higher for temperature range of 21 to $28^{\circ} \mathrm{C}$ but afterward decreased at high module temperature.

The module efficiency decreases with increase in module temperature as shown in Figure 9. The average module efficiency decreases by about $8.85 \%, 5.25 \%$, and $26 \%$ for c$\mathrm{Si}, \mathrm{p}-\mathrm{Si}$, and a-Si modules, respectively, with the increase of module temperature from 22 to $33^{\circ} \mathrm{C}$. Due to high module temperature, the monthly average module efficiency in March is lower than the other two months (Figure 12).

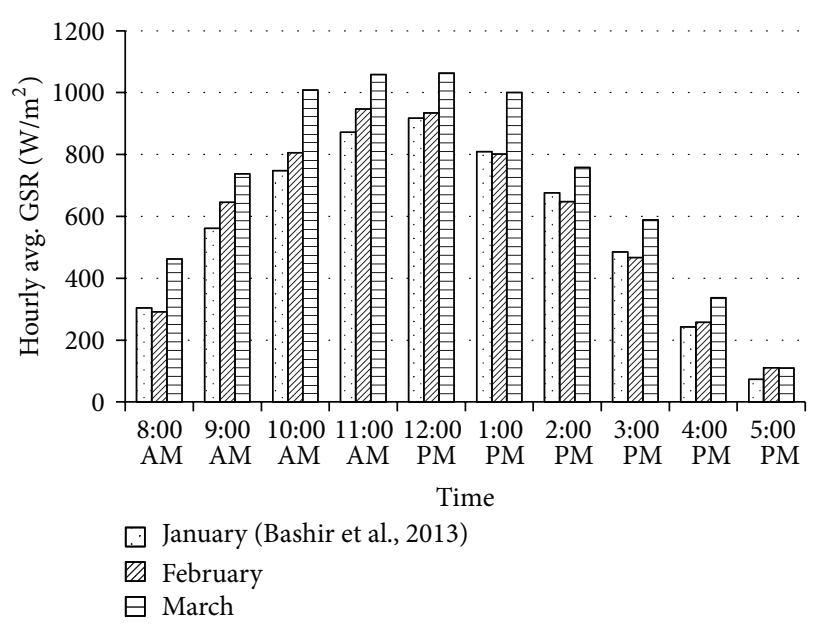

FIgURE 3: Bar diagram showing the hourly average global solar irradiance for January [26], February, and March.

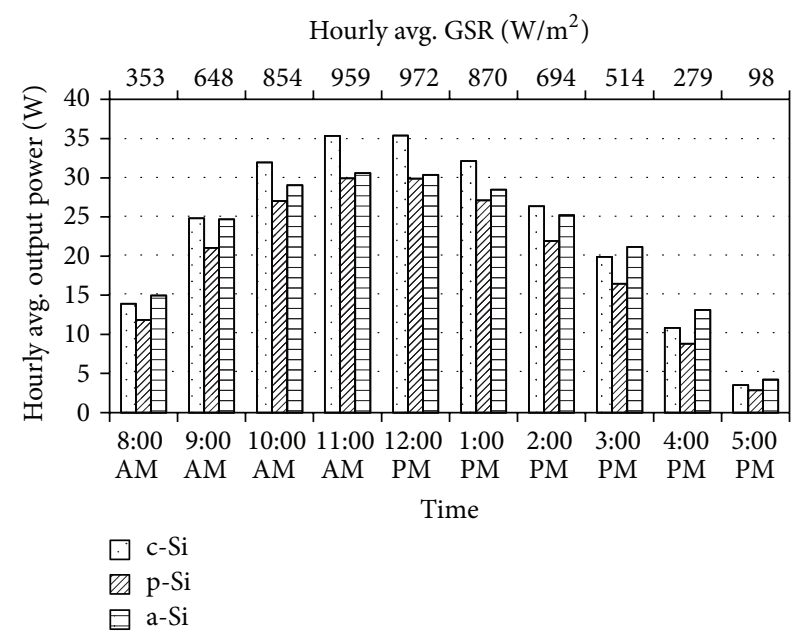

FIGURE 4: Bar diagram of hourly average output power of monocrystalline, polycrystalline, and amorphous silicon modules measured for January [26], February, and March.

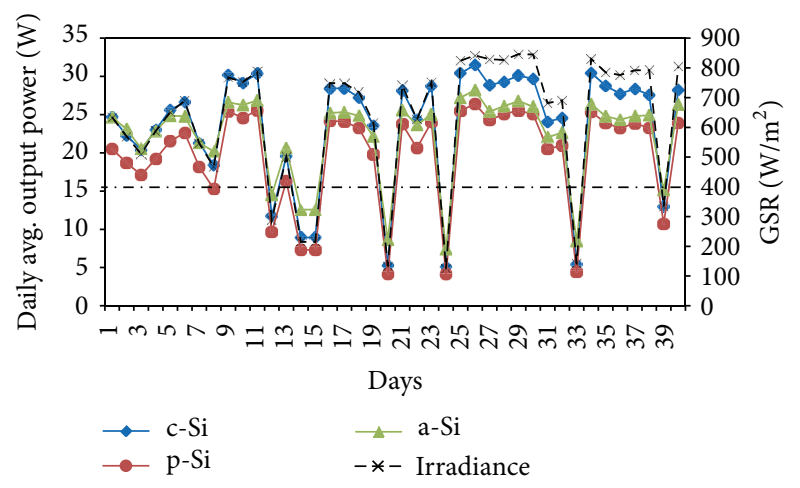

FIGURE 5: Variation of daily average output power of all days of study. 
TABle 2: Comparison of present global solar irradiance with Akhter et al. [28].

\begin{tabular}{|c|c|c|c|c|c|c|}
\hline & \multicolumn{6}{|c|}{ Average global horizontal irradiance $\left(\mathrm{W} / \mathrm{m}^{2}\right)$ of clear sky days } \\
\hline & \multicolumn{3}{|c|}{ Measured values } & \multicolumn{3}{|c|}{ Akhter et al. [28] } \\
\hline & $9: 00 \mathrm{am}$ & $12: 00 \mathrm{pm}$ & $3: 00 \mathrm{pm}$ & 9:00 am & $12: 00 \mathrm{pm}$ & 3:00 pm \\
\hline January [26] & 315 & 612 & 324 & 277 & 651 & 409 \\
\hline February & 432 & 625 & 445 & 341 & 674 & 516 \\
\hline March & 494 & 711 & 394 & 461 & 762 & 424 \\
\hline
\end{tabular}

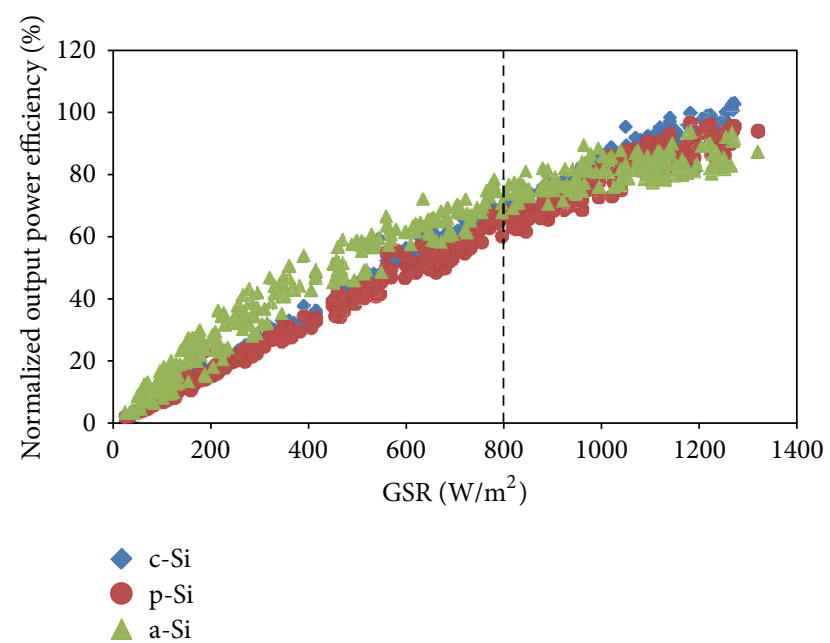

FIGURE 6: Scattering plot of normalized output power efficiency of monocrystalline, polycrystalline, and amorphous silicon modules versus global solar radiations measured from 8 am to $5 \mathrm{pm}$.

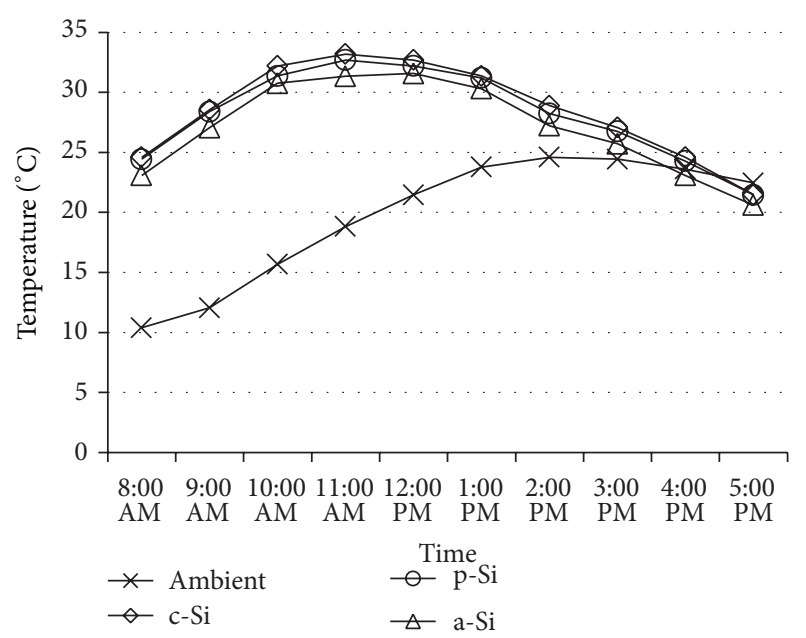

FIGURE 7: Variation of hourly average module and ambient temperatures from 8 am to $5 \mathrm{pm}$.

Like module efficiency, performance ratio also showed a decreasing trend with module temperature (Figure 10), also reported by Rehman and El-Amin [10]. The c-Si, p$\mathrm{Si}$, and a-Si module have shown average PR decrement of about $5.6 \%, 9.3 \%$, and $22.6 \%$, respectively, for increase of module temperature from 22 to $33^{\circ} \mathrm{C}$. The a-Si module has much higher PR as compared to crystalline modules for low

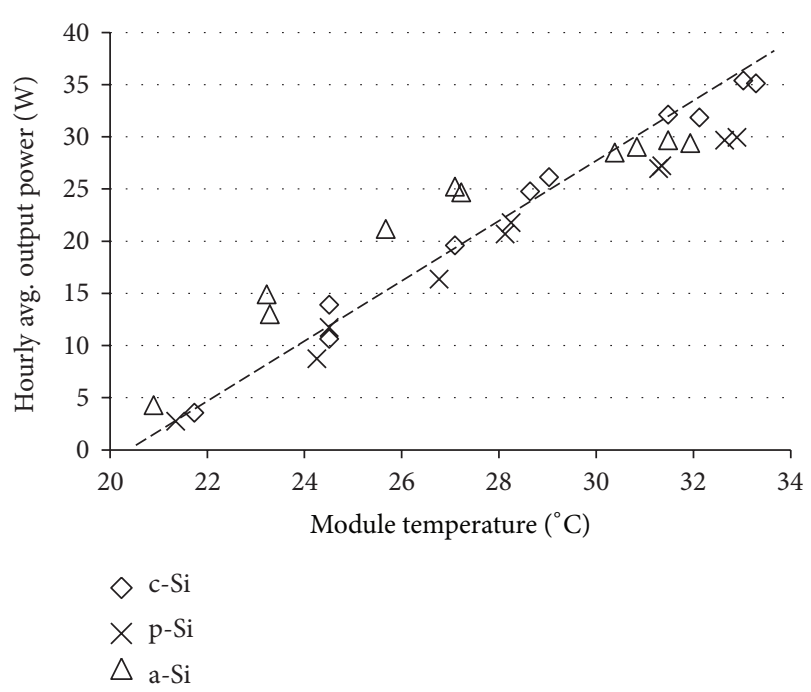

FIGURE 8: Scattering plot of hourly average output power versus the module temperature of monocrystalline, polycrystalline, and amorphous silicon modules measured from 8 am to $5 \mathrm{pm}$.

temperature range and shows a sharp decrease at high module temperature.

3.2. Module Efficiency Analysis. The module efficiency of PV modules at outdoor conditions is different from STC due to varying outdoor conditions. The hourly average module efficiency of three modules is shown in Figure 11. The module efficiency has shown inverse relation with the solar irradiance (also reported by $[9,30,31])$. At $12 \mathrm{pm}$, efficiency of modules was lowest corresponding to the highest solar irradiance. The decrease in average module efficiency was $7.8 \%, 8.2 \%$, and $22.1 \%$ for c-Si, p-Si, and a-Si modules, respectively, with $175 \%$ increase of average global solar radiation from 8 am to $12 \mathrm{pm}$ for three months. At $5 \mathrm{pm}$, sudden decrease in irradiance lowers the module efficiency. The c-Si module is well known for high module efficiency and has shown high module efficiency than $\mathrm{p}-\mathrm{Si}$ and a-Si modules. The cSi module has shown $37 \%$ and $134 \%$ higher average module efficiency than $\mathrm{p}$-Si and a-Si modules, respectively, as shown in Figure 12. The lowest efficiency of a-Si module is due to its large module area compared to crystalline silicon modules as shown in Table 1.

3.3. Performance Ratio Analysis. The performance ratio PR represents the performance of the PV modules at outdoor 


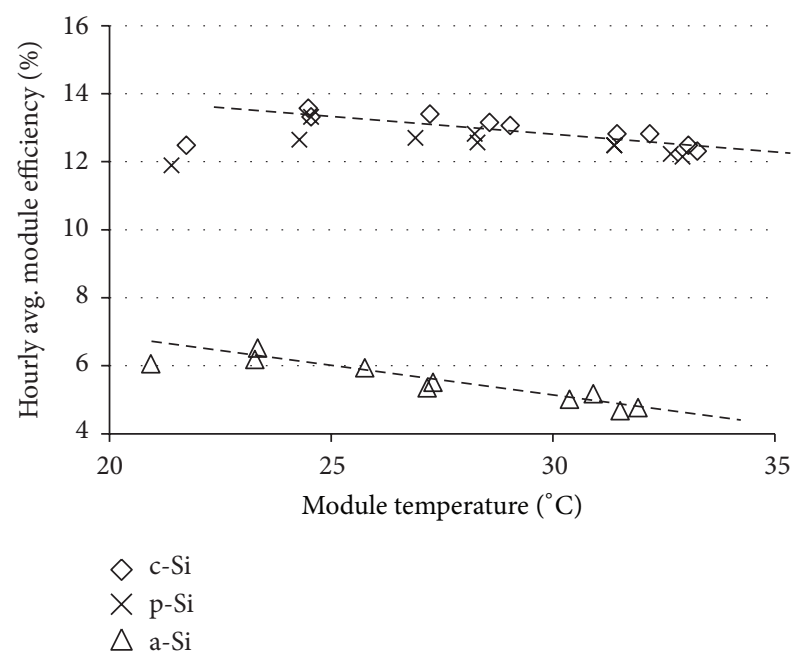

FIGURE 9: Variation of hourly average module efficiency with the module temperature of monocrystalline, polycrystalline, and amorphous silicon modules measured from 8 am to $5 \mathrm{pm}$.

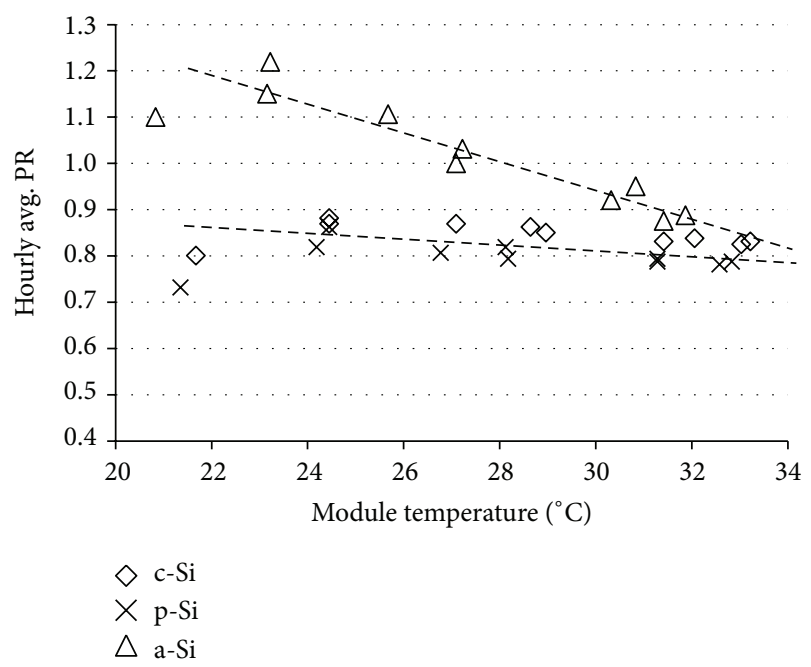

FIGURE 10: Scattering plot of hourly average performance ratio versus the module temperature of monocrystalline, polycrystalline, and amorphous silicon modules measured from 8 am to $5 \mathrm{pm}$.

conditions compared to their performance under STC. It is observed that PR has a decreasing trend with the increase of global solar radiation and modules have lowest average PR at highest average global solar radiation as shown in Figure 13. It was found that average PR decreased by $5.68 \%$, $9.3 \%$, and $22.6 \%$ for c-Si, p-Si, and a-Si module, respectively, with increase of average solar irradiance of $175 \%$ from 8 am to $12 \mathrm{pm}$ for winter months. The a-Si module due to its better performance in low light condition showed much higher PR than the crystalline silicon modules at low irradiance; however, it decreased sharply with increase in solar irradiance. The c-Si module, however, showed better performance at high irradiance with a PR close to a-Si module at this condition. It can be seen from Figure 14 that a-Si module is superior in terms of average PR due to its better performance and better light absorption at low light conditions. The a-Si module has

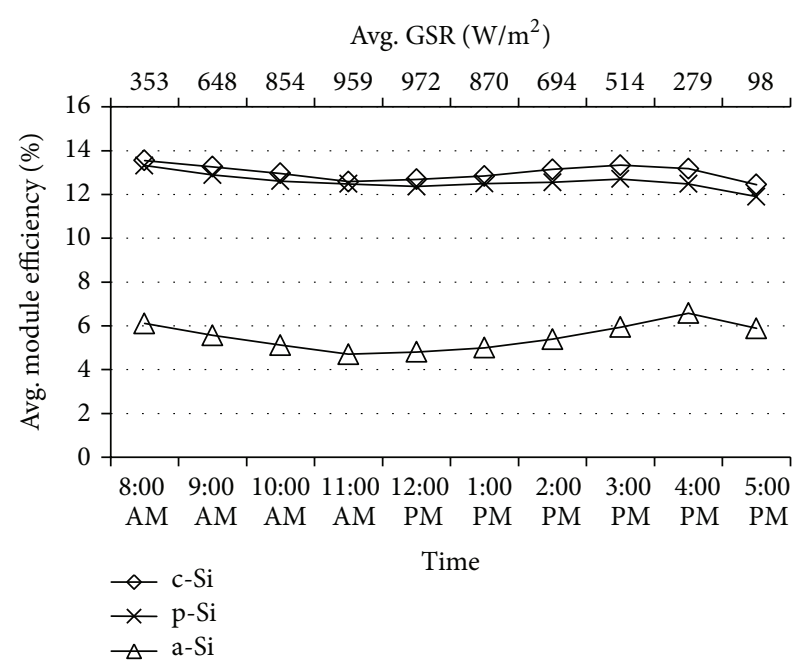

FIGURE 11: Variation of hourly average module efficiency of monocrystalline, polycrystalline, and amorphous silicon modules from 8 am to $5 \mathrm{pm}$.

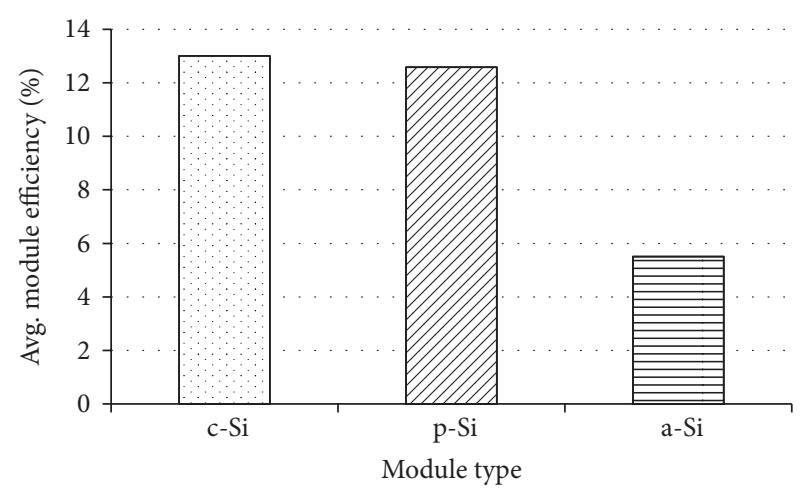

FIGURE 12: Average module efficiency of monocrystalline, polycrystalline, and amorphous silicon modules (January, February, and March).

shown $21.2 \%$ and $28.7 \%$ higher average PR than c-Si and pSi modules, respectively. The PR of p-Si module was lowest, close to the c-Si module.

\section{Conclusion}

Within the scope of this research, the hourly output power, module efficiency, and performance ratio of three modules were measured and variation of these parameters with solar irradiance and backside surface temperature of PV modules was investigated. The study concluded that output power of modules increases linearly with increase of solar irradiance. The c-Si module has shown high average output power but aSi has shown higher normalized output power efficiency due to its better performance in low irradiance condition.

The overall average module efficiency of c-Si module was $13.01 \%$, which is higher than average module efficiency of other two modules. Results depict that module efficiency shown a decreasing trend with increase of solar irradiance 


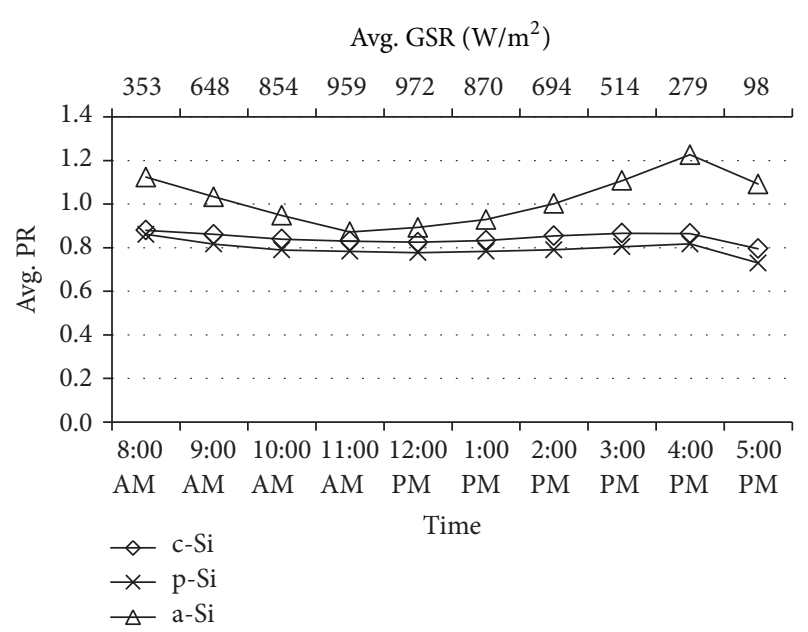

FIGURE 13: Variation of hourly average performance ratio of monocrystalline, polycrystalline, and amorphous silicon modules from 8 am to $5 \mathrm{pm}$.

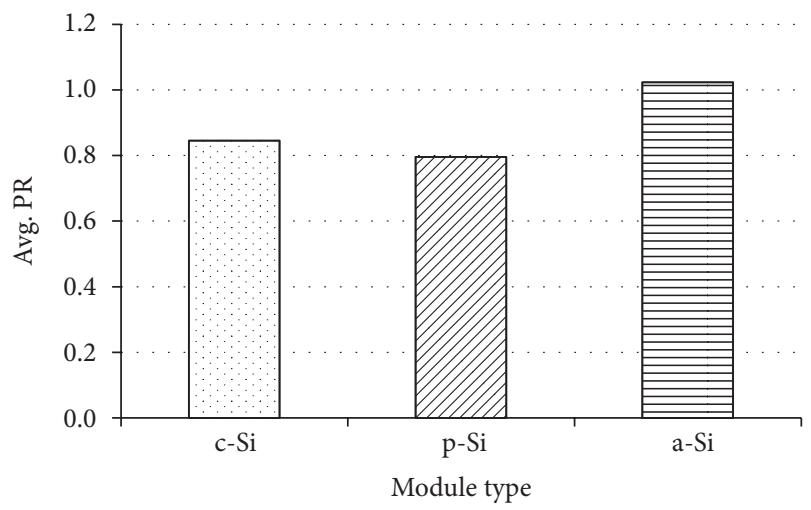

FIGURE 14: Average performance ratio of monocrystalline, polycrystalline, and amorphous silicon modules (January, February, and March).

and module temperature. The average module efficiency decreased by about $8.85 \%, 4.5 \%$, and $26 \%$ for c-Si, p-Si, and a-Si modules, respectively, with the increase of module temperature from 22 to $33^{\circ} \mathrm{C}$.

Due to light absorbing characteristic, a-Si module has shown higher average PR. The PR also showed a decreasing trend with solar irradiance and module temperature. The c$\mathrm{Si}, \mathrm{p}-\mathrm{Si}$, and a-Si module have shown average PR decrement of about $5.6 \%, 4.8 \%$, and $25.8 \%$, respectively, for increase of module temperature from 22 to $33^{\circ} \mathrm{C}$.

\section{Nomenclature}

AM: Air mass

$A_{a}:$ Active area of module $\left(\mathrm{m}^{2}\right)$

a-Si: Amorphous silicon module

c-Si: Monocrystalline silicon module

GSR: Global solar radiation $\left(\mathrm{W} / \mathrm{m}^{2}\right)$

E: $\quad$ Solar irradiance $\left(\mathrm{W} / \mathrm{m}^{2}\right)$

$E_{D}$ : Direct solar irradiance $\left(\mathrm{W} / \mathrm{m}^{2}\right)$
$E_{H}$ : Solar irradiance at horizontal surface $\left(\mathrm{W} / \mathrm{m}^{2}\right)$

$I_{m}: \quad$ Maximum current (A)

$I_{\text {sc }}$ : Short circuit current (A)

POA: Plane of array

PR: Performance ratio

$P_{m}: \quad$ Maximum power $(\mathrm{W})$

$P_{\text {mea }}$ : Measured power output (W)

PV: Photovoltaic

p-Si: Polycrystalline silicon module

STC: Standard test condition

$V_{m}: \quad$ Maximum voltage $(\mathrm{V})$

$V_{\text {oc }}: \quad$ Open circuit voltage $(\mathrm{V})$

$\delta: \quad$ Zenith angle

$\eta_{p}: \quad$ Normalized power output efficiency

$\eta_{\text {mod }}$ : Module efficiency.

\section{Conflict of Interests}

The authors declare that there is no conflict of interests regarding the publication of this paper.

\section{References}

[1] M. Fuentes, G. Nofuentes, J. Aguilera, D. L. Talavera, and M. Castro, "Application and validation of algebraic methods to predict the behaviour of crystalline silicon PV modules in Mediterranean climates," Solar Energy, vol. 81, no. 11, pp. 13961408, 2007.

[2] N. Amin, C. W. Lung, and K. Sopian, "A practical field study of various solar cells on their performance in Malaysia," Renewable Energy, vol. 34, no. 8, pp. 1939-1946, 2009.

[3] A. J. Carr and T. L. Pryor, "A comparison of the performance of different PV module types in temperate climates," Solar Energy, vol. 76, no. 1-3, pp. 285-294, 2004.

[4] K. Akhmad, A. Kitamura, F. Yamamoto, H. Okamoto, H. Takakura, and Y. Hamakawa, "Outdoor performance of amorphous silicon and polycrystalline silicon PV modules," Solar Energy Materials and Solar Cells, vol. 46, no. 3, pp. 209-218, 1997.

[5] O.-M. Midtgard, T. O. Sætre, G. Yordanov, A. G. Imenes, and C. L. Nge, "A qualitative examination of performance and energy yield of photovoltaic modules in southern Norway," Renewable Energy, vol. 35, no. 6, pp. 1266-1274, 2010.

[6] M. A. Eltawil and Z. Zhao, "Grid-connected photovoltaic power systems: technical and potential problems-a review," Renewable and Sustainable Energy Reviews, vol. 14, no. 1, pp. 112129, 2010 .

[7] P. Singh, S. N. Singh, M. Lal, and M. Husain, "Temperature dependence of I-V characteristics and performance parameters of silicon solar cell," Solar Energy Materials and Solar Cells, vol. 92, no. 12, pp. 1611-1616, 2008.

[8] M. Mattei, G. Notton, C. Cristofari, M. Muselli, and P. Poggi, "Calculation of the polycrystalline PV module temperature using a simple method of energy balance," Renewable Energy, vol. 31, no. 4, pp. 553-567, 2006.

[9] D. Meneses-Rodríguez, P. P. Horley, J. González-Hernández, Y. V. Vorobiev, and P. N. Gorley, "Photovoltaic solar cells performance at elevated temperatures," Solar Energy, vol. 78, no. 2, pp. 243-250, 2005. 
[10] S. Rehman and I. El-Amin, "Performance evaluation of an off grid photovoltaic system in Saudi Arabia," Energy, vol. 46, pp. 451-458, 2012.

[11] Y. K. Sanusi, G. R. Fajinmi, and E. B. Babatunde, "Effects of ambient temperature on the performance of a photovoltaic solar system in a tropical area," The Pacific Journal of Science and Technology, vol. 12, no. 2, pp. 176-180, 2011.

[12] D. L. Staebler and C. R. Wronski, "Reversible conductivity changes in discharge-produced amorphous Si ", Applied Physics Letters, vol. 31, p. 292, 1997.

[13] M. Sadok and A. Mehdaoui, "Outdoor testing of photovoltaic arrays in the Saharan region," Renewable Energy, vol. 33, no. 12, pp. 2516-2524, 2008.

[14] E. L. Meyer and E. E. van Dyk, "Assessing the reliability and degradation of photovoltaic module performance parameters," IEEE Transactions on Reliability, vol. 53, no. 1, pp. 83-92, 2004.

[15] S. Rahman, M. A. Khallat, and Z. M. Salameh, "Characterization of insolation data for use in photovoltaic system analysis models," Energy, vol. 13, no. 1, pp. 63-72, 1988.

[16] A. N. Celik, "Long-term energy output estimation for photovoltaic energy systems using synthetic solar irradiation data," Energy, vol. 28, no. 5, pp. 479-493, 2003.

[17] M. Mani and R. Pillai, "Impact of dust on solar photovoltaic (PV) performance: research status, challenges and recommendations," Renewable and Sustainable Energy Reviews, vol. 14, no. 9, pp. 3124-3131, 2010.

[18] H. Jiang, L. Lu, and K. Sun, "Experimental investigation of the impact of airborne dust deposition on the performance of solar photovoltaic (PV) modules," Atmospheric Environment, vol. 45, no. 25, pp. 4299-4304, 2011.

[19] M. Catelani, L. Ciani, L. Cristaldi, M. Faifer, M. Lazzaroni, and M. Rossi, "Characterization of photovoltaic panels: the effects of dust," in Proceedings of the 2nd IEEE Energycon Conference \& Exhibition, Advances in Energy Conversion Symposium, 2012.

[20] L. Cristaldi, M. Faifer, and M. Rossi, "Economical evaluation of PV system losses due to the dust and pollution," in Proceedings of the 2nd IEEE energycon Conference \& Exhibition, Advances in Energy Conversion Symposium, 2012.

[21] M. Catelani, L. Ciani, L. Cristaldi, M. Faifer, and M. Lazzaroni, "Electrical performances optimization of Photovoltaic Modules with FMECA approach," Measurement, vol. 46, pp. 3898-3909, 2013.

[22] S. Mekhilef, R. Saidur, and R. Kamalisarvestani, "Effect of dust, humidity and air velocity on efficiency of photovoltaic cells," Renewable and Sustainable Energy Reviews, vol. 16, no. 5, pp. 2920-2925, 2012.

[23] M. Ashraf Chaudhry, R. Raza, and S. A. Hayat, "Renewable energy technologies in Pakistan: prospects and challenges," Renewable and Sustainable Energy Reviews, vol. 13, no. 6-7, pp. 1657-1662, 2009.

[24] I. Ulfat, F. Javed, F. A. Abbasi et al., "Estimation of solar energy potential for Islamabad, Pakistan," Energy Procedia, vol. 18, pp. 1496-1500, 2013.

[25] U. K. Mirza, M. Mercedes Maroto-Valer, and N. Ahmad, "Status and outlook of solar energy use in Pakistan," Renewable and Sustainable Energy Reviews, vol. 7, no. 6, pp. 501-514, 2003.

[26] M. A. Bashir, H. M. Ali, M. Ali, and A. M. Siddiqui, "An experimental investigation of performance of photovoltaic modules in Pakistan," Thermal Science Journal, p. 134, 2013.

[27] M. A. Munoz-Garc1, A. Marin, M. C. Alonso-Garcia, and F. Chenlo, "Characterization of thin film PV modules under standard test conditions: results of indoor and outdoor measurements and the effects of sunlight exposure," Solar Energy, vol. 86, pp. 3049-3056, 2012.

[28] P. Akhter, A. Baig, and A. Mufti, "Clear sky solar insulation data for Islamabad," International Journal of Solar Energy, vol. 10, pp. 155-159, 1991.

[29] S. M. Sze, Physics of Semiconductor Devices., John Wiley \& Sons, New York, NY, USA, 2nd edition, 1981.

[30] T. Markvart, Solar Electricity, University of Southampton UK, John Wiley \& Sons Ltd. Baffin's lane, Chichester, UK, 1994.

[31] J. L. Stone, "Photovoltaics: unlimited electrical energy from the sun," Physics Today, vol. 46, no. 9, pp. 22-29, 1993. 

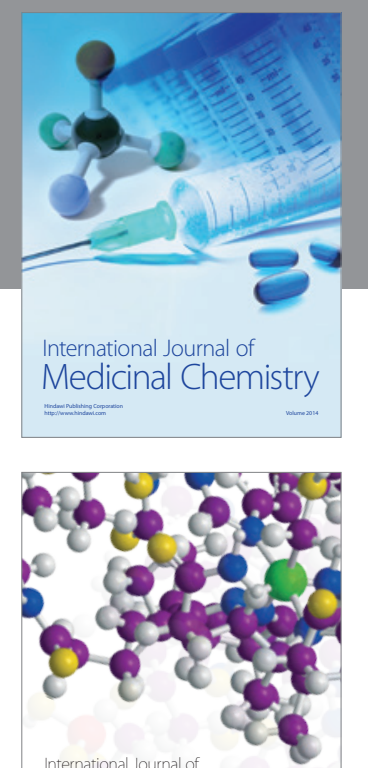

\section{Carbohydrate} Chemistry

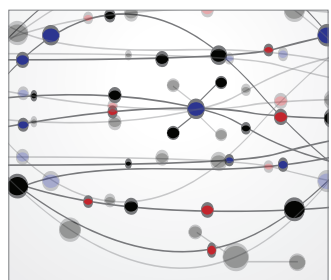

The Scientific World Journal
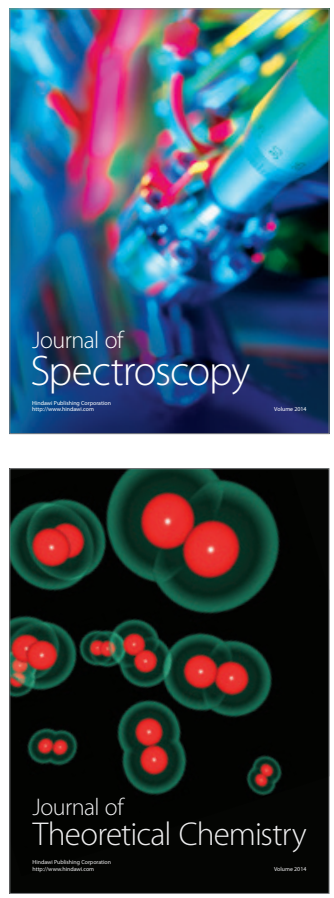
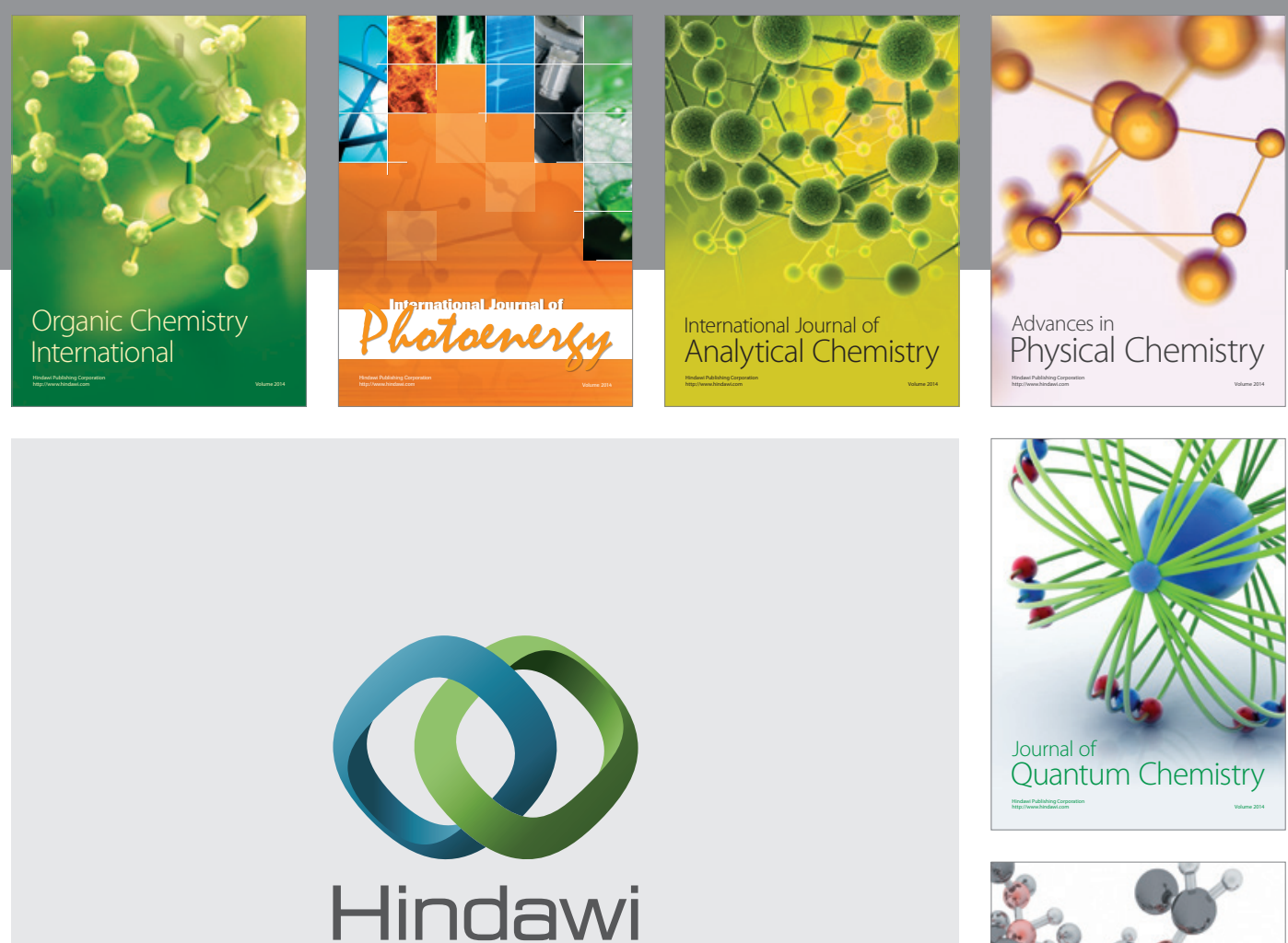

Submit your manuscripts at

http://www.hindawi.com

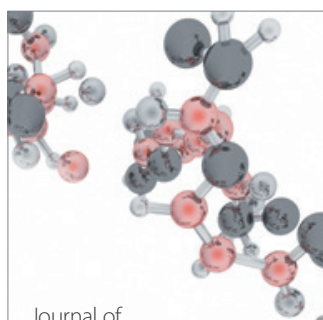

Analytical Methods

in Chemistry

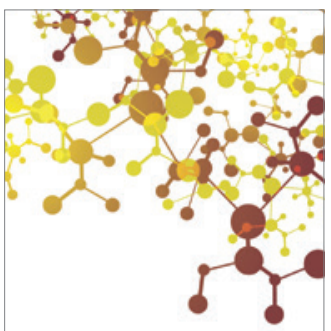

Journal of

Applied Chemistry

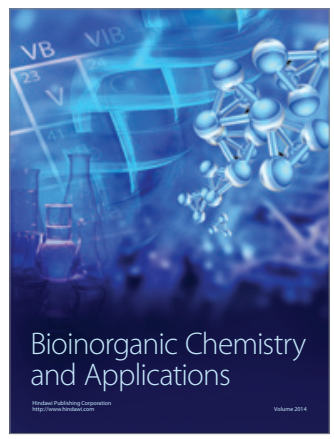

Inorganic Chemistry
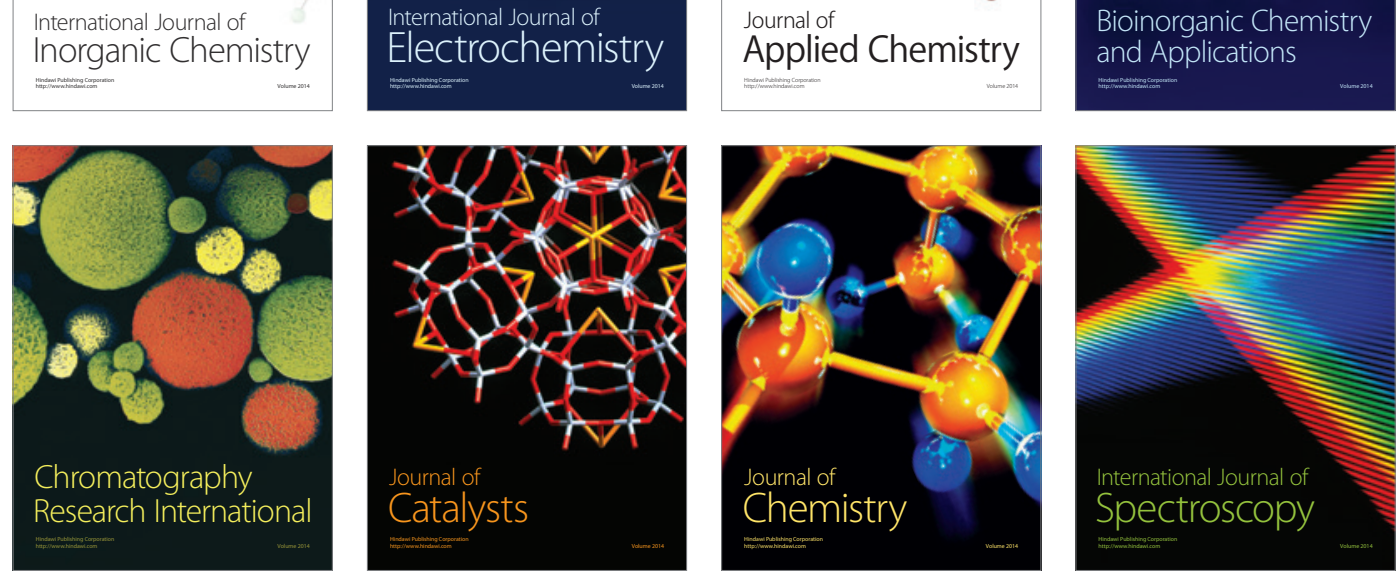